\title{
The effects of managerial systems on helminth infection in free- range chickens from northern Paraná, Brazil
}

\section{Os efeitos do sistema de manejo na infecção por helmintos em galinhas caipiras do norte do Paraná, Brasil}

\author{
Fernando Emmanuel Gonçalves Vieira'; Milton Hissashi Yamamura²; \\ Roberta Lemos Freire²; Selwyn Arlington Headley²*
}

\begin{abstract}
The effects of managerial systems on the occurrence of gastrointestinal helminths in Free-Range Chickens (FRCs) from northern Paraná, Brazil were investigated. The most predominant $(23.3 \%$; $61 / 262)$ cestode observed was Raillietina cesticillus; Heterakis gallinarum $(71.4 \%$; 187/262) and Ascaridia galli $(45 \% ; 118 / 262)$ were the predominant nematodes; Postharmostomum commutatum was the only trematode observed in $2.7 \%$ (7/262) of FRCs. The most elevated parasitic burdens were associated with Heterakis gallinarum, Ascaridia galli, and Raillietina cesticillus. Significant $(p \leq 0.05)$ associations were observed when the effects of the types of bedding, soil type, and fence restriction of FRCs were considered relative to the possibility of helminthiasis. The type of bedding, the length of the sanitary break, and the presence of shading significantly $(p \leq 0.05)$ influenced the possibility of FRCs being infected by $H$. gallinarum. Most parameters evaluated were significantly associated with infection of FRCs by $A$. galli. These findings suggest that FRCs from northern Paraná are infected by a wide-range of gastrointestinal helminths, but more frequently by R. cesticillus, H. gallinarum, and A. galli. Moreover, the type of floor bedding, the soil type, and the usage of fences in the management of FRCs is directly related to gastrointestinal helminthiasis.
\end{abstract}

Key words: Free-range chickens, helminthiasis, Heterakis gallinarum, Ascaridia galli

\section{Resumo}

Foram investigados os efeitos dos sistemas de manejo sobre a ocorrência de helmintos gastrintestinais em galinhas caipiras (GCs) do norte do Paraná, Brasil. O cestódeo predominante $(23,3 \% ; 61 / 262)$ foi Raillietina cesticillus; entre os nematódeos Heterakis gallinarum (71,4\%, 187/262) e Ascaridia galli (45\%, 118/262); Postharmostomum commutatum foi o único trematódeo encontrado em 2,7\% (7/262) das GCs. As cargas parasitárias mais elevadas foram associadas à Heterakis gallinarum, Ascaridia galli e Raillietina cesticillus. Associações significantes $(p \leq 0,05)$ quanto às helmintíases foram observadas em relação ao tipo de cama, ao tipo de solo e à presença de restrição das GCs em áreas cercadas. O tipo de cama, o tempo do vazio sanitário e a presença de sombreamento influenciaram significativamente ( $p \leq$ $0,05)$ quanto à infecção por $H$. gallinarum. A maioria dos parâmetros avaliados foram significativamente associados à infecção das CGs por $A$. galli. Estes resultados sugerem que GCs do norte do Paraná são infectadas por uma ampla variedade de helmintos gastrintestinais, porém mais frequentemente por $R$. cesticillus, $H$. gallinarum e $A$. galli. Além disso, o tipo de cama de forração, o tipo de solo e o uso de

\footnotetext{
${ }^{1}$ Prof., Universidade Estadual do Norte do Paraná, UNOPAR, Jacarezinho, Paraná, Brasil. E-mail: fernando egv@hotmail.com

2 Profs. Drs., Dept ${ }^{\circ}$ de Medicina Veterinária Preventiva, Universidade Estadual de Londrina, UEL, Londrina, PR, Brasil. E-mail: yamamura@uel.br; rlfreire1966@gmail.com; selwyn.headley@uel.br

* Author for correspondence
} 
cercas no manejo das GCs são variáveis que estão diretamente relacionados à presença de helmintíases gastrintestinais.

Palavras-chave: Galinhas caipiras, helmintíases, Heterakis gallinarum, Ascaridia galli

\section{Introduction}

The free-range method of chicken production is a semi-intensive system of farming that aims to increase the welfare of animals. The Brazilian Ministry of Agriculture, Livestock and Supply, has stipulated that free-range chickens (FRCs) can be reared in pens for a maximum of 25 days, that these bird must have access to pastures with a stocking density of $3 \mathrm{~m}^{2} /$ bird, and be slaughtered at no less than 85 days of age (MAPA, 1999). Further, FRCs are not exposed to biologicals for the control of diseases (BERG, 2002; CARDOZO; YAMAMURA, 2004). Nevertheless, these birds are most frequently infected by parasites relative to chickens reared in pens (FOSSUM et al., 2009), and are more prone to infection by helminths than commercial layers and broilers (RABBI et al., 2006). Therefore, the control of the rearing environment is of great importance in reducing parasitic infections.

Nematodes (roundworms), cestodes (tapeworms), and trematodes (flatworms) are frequent helminth parasites of FRCs (RUFF, 1999; CARDOZO; YAMAMURA, 2004), that can result in economic losses to the poultry industry. Reports of gastrointestinal parasites in FRCs have originated predominantly from the African (SSENYONGA, 1982; ESHETU et al., 2001; MAGWISHA et al., 2002; LUKA; NDAMS, 2007; YORIYO et al., 2008; DUBE et al., 2010), Asian (RABBI et al., 2006; ESLAMI et al., 2009; RAHMAN et al., 2009), and American (MACHADO et al., 1980; REIS et al., 1980; VIERO, 1984; COSTA et al., 1986; OLIVARES et al., 2006) continents. However, most of these have only described the occurrence/ frequency of helminths in FRCs. Alternatively, it was demonstrated that the rate of infections of gastrointestinal helminths in FRCs is influenced by the ecological and agricultural aspects of the habitat (ESHETU et al., 2001) and the type of birds being reared (MAGWISHA et al., 2002; RABBI et al., 2006). Nevertheless, few studies investigating the effects of managerial systems on helminthiasis in FRCs were located when major databases were accessed, and we did not identify a similar study performed in Brazil. This study evaluated the possible relationships between several managerial aspects of the production of FRCs and the risk of helminthic infection, since an understanding of this relationship may contribute to the control of helminths in free-range chickens.

\section{Materials and Methods}

\section{Study area}

This study was done in the northern region of the state of Paraná, southern Brazil. FRCs reared in the following cities were included: Jacarezinho, Santo Antônio da Platina, Cambará, Barra do Jacaré, Cornélio Procópio, Santa Mariana, Apucarana, and Conselheiro Mairinck (Figure 1). These cities are located within latitudes $22^{\circ} 30^{\prime} 0$ ' and $24^{\circ} 0$ ' 0 "' and between longitudes $49^{\circ} 30^{\prime} 0^{\prime \prime}$ ' and 52³0'0"(BHERING; SANTOS, 2008). This is a subtropical region, which predominantly consist of clay soil, has evenly distributed rainy seasons, and an average annual temperature of $22^{\circ} \mathrm{C}$.

\section{Sample size and sampling methodology}

The size of the conglomerate sample (262 chickens) was determined by the software Epi Info 3.5.4 (DEAN et al., 1996). To calculate the minimum sample size, an expected frequency of $50 \%$, a worst acceptable of $6 \%$, and a confidence level of $95 \%$ were used. During October 2008 and 
December 2009, 262 FRCs submitted for slaughter from 14 rural districts of the eight selected cities from northern Paraná were evaluated; 40 sample collections were done during this period, each sample contained five to ten organs. The collections were determined by the necessity to slaughter the chickens by farmers for consumption or marketing.
The size of the sample obtained from each farm was proportional to the number of birds slaughtered during the period. The weight of the birds at slaughter varied between 2 to $2.4 \mathrm{~kg}$; all birds demonstrated good body condition. Therefore, it was not possible to determine performance losses caused by helminths.

Figure 1. Google Earth image demonstrating the geographical locations of the cities (yellow pins) in northern Paraná where this study was done.

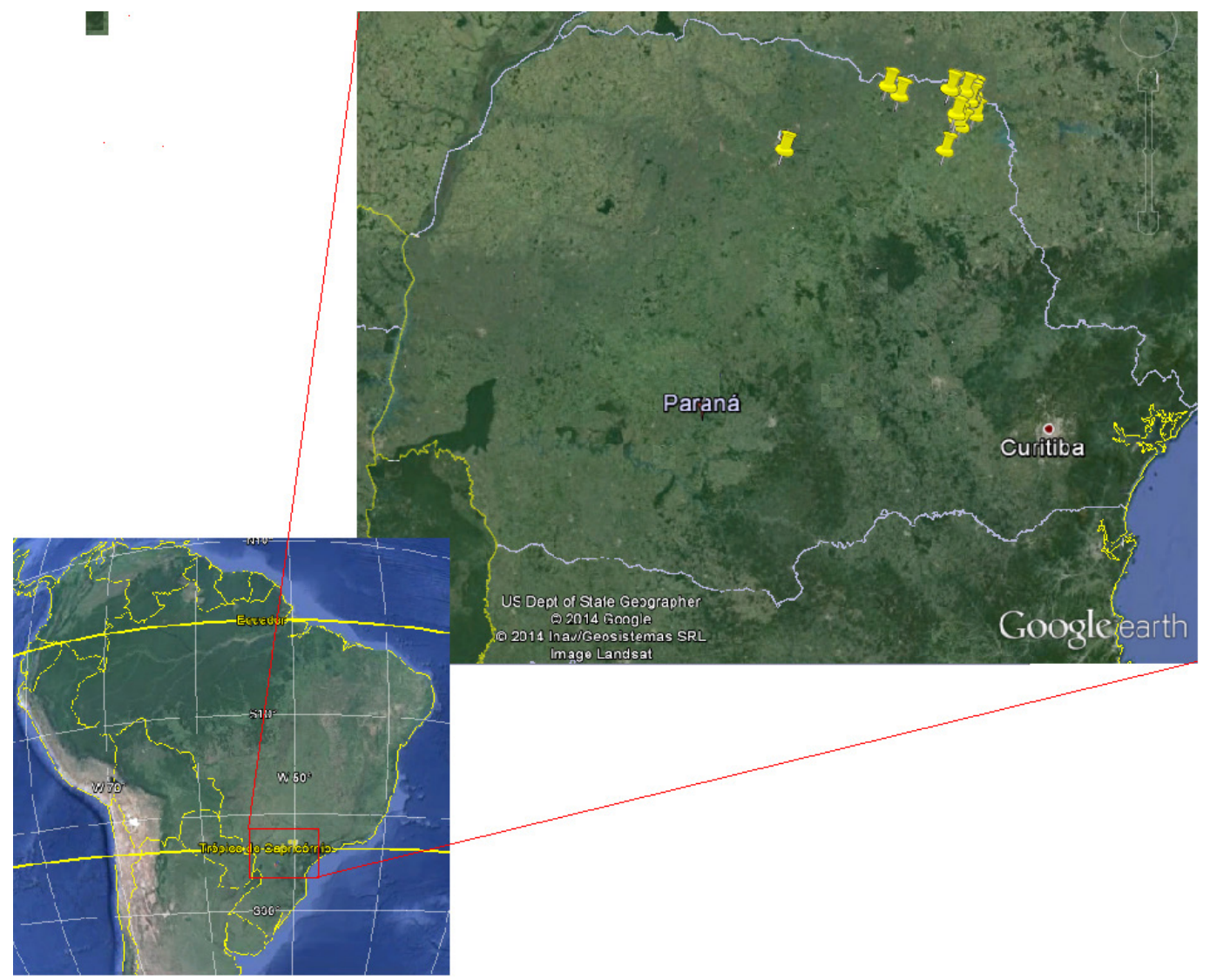

\section{Parasitological examinations}

The trachea, the gastrointestinal tract, and bursa of Fabricius of all FRCs were collected and transported refrigerated to the Laboratory of Veterinary Parasitology, Universidade Estadual de Londrina, where they were opened and examined. The luminal surfaces of all organs were scraped and the contents filtered by three sieves of different diameters $(150 \mu \mathrm{m}, 425 \mu \mathrm{m}$, and
$600 \mu \mathrm{m})$ to separate the helminths by category (PAVANELLI, 1981). The contents were then examined under a stereomicroscope; all helminths collected were immersed in Railliet-Henry fluid, fixed, and identified. Identification was based on the morphological characteristics of helminths (YAMAGUTI, 1959, 1961; TRAVASSOS et al., 1969; SOULSBY, 1982; SCHMIDT, 1986). The frequencies of the helminths identified during 
this study were then compared with similar investigations done in Brazil.

\section{Epidemiological survey}

An epidemiological survey was designed to investigate whether the characteristics associated with the production systems used at the 14 farms investigated have any influence of infection by helminths. The chicken farmers who consented to the study were interviewed at each farm during which one questionnaire was applied, using the closed question format (THRUSFIELD, 2005). The possible relationship between data from each farm was then related with the results of parasitological exams of each chicken by the Epi Info 3.5.4 (DEAN et al., 1996). All farmers indicated that anthelmintic therapy was not used during the period of this survey. The parameters evaluated included: type of bedding; age at slaughter; age released from cages; soil type; stocking capacity; rearing systems; water source; rearing of other avian species; presence of shading, and sanitary break. The feed administered to all chickens was similar at all farms (pasture and cereal), and thus not used as a variable. The possible association between these parameters relative to the occurrence of infection was determined by using the odds ratio (OR) with a confidence interval (CI) of $95 \%$.

\section{Statistical analyses}

The frequency of an individual helminth species was determined by calculating the percentage of the host population infected (THRUSFIELD, 2005). The Miettinen formula was used to calculate the confidence interval (CI). The ratio of the birds exposed to the variables relative to the ratio of birds not exposed (Ratio of Cross-product) was used to determine the OR of the variables investigated (RUMEL, 1986); $p \leq 0.05$ was considered as significant. All statistical analyses were done by using the software Epi Info 3.5.4 (DEAN et al., 1996).

\section{Results}

\section{Distribution of helminths}

The age of the FRCs evaluated varied between 85 and 120 days. The distribution of helminths in FRCs within the regions evaluated is given in Table 1. Chickens from all farms evaluated were infected by gastrointestinal parasites. However, not all FRCs examined were parasitized; the frequency of parasitism varied between $8-100 \%$, with an overall average parasitism of $76.3 \%$. No seasonal effect on infection was observed.

Most $(85.9 \% ; 225 / 262)$ of the FRCs examined contained at least one example of a helminth species. These represented 16 genera and 23 species of helminths that were distributed in cestodes $(n=6)$, nematodes $(n=16)$, and trematode $(n=1)$. The prevalence of helminths identified and their habitats are given in Table 2. Raillietina cesticillus was the most prevalent cestode, and was identified in $23.3 \%(61 / 262)$ of the FRCs evaluated; Heterakis gallinarum and Ascaridia galli were the predominant nematodes observed, and occurred in $71.4 \%(187 / 262)$ and $45 \%(118 / 262)$ of all FRCs, respectively. The only trematode identified, Postharmostomum commutatum, was observed in $2.7 \%(7 / 262)$ of the FRCs evaluated. The most elevated parasitic burdens were associated with Heterakis gallinarum (21.1 helminths/infected bird), Ascaridia galli (12.2 helminths/infected bird) and Raillietina cesticillus ( 8.7 helminths/infected bird), which corresponded to 3,$939 ; 1,435$ and 531 examples respectively. Additionally, this study might represent the first description of helminthiasis due to Physaloptera truncata and Subulura brumpti in FRCs from southern Brazil. 
Table 1. Distribution and parasitism frequency in free-range chickens from rural areas of southern Brazil.

\begin{tabular}{|c|c|c|c|c|}
\hline \multirow{2}{*}{ Study locations } & \multirow{2}{*}{ Rural areas } & \multicolumn{3}{|c|}{ Free-range chickens evaluated } \\
\hline & & Total & Positive & $\%$ \\
\hline \multirow[t]{4}{*}{ Santo Antonio da Platina } & A & 9 & 9 & 100 \\
\hline & B & 12 & 12 & 100 \\
\hline & $\mathrm{C}$ & 9 & 9 & 100 \\
\hline & $\mathrm{D}$ & 5 & 5 & 100 \\
\hline Cambará & $\mathrm{E}$ & 25 & 6 & 24 \\
\hline Barra do Jacaré & $\mathrm{F}$ & 64 & 60 & 93.3 \\
\hline \multirow{3}{*}{ Santa Mariana } & G & 25 & 4 & 16 \\
\hline & $\mathrm{H}$ & 7 & 7 & 100 \\
\hline & I & 6 & 6 & 100 \\
\hline Conselheiro Mairink & $\mathrm{J}$ & 50 & 46 & 92 \\
\hline Apucarana & K & 25 & 2 & 8 \\
\hline \multirow[t]{2}{*}{ Jacarezinho } & $\mathrm{L}$ & 5 & 5 & 100 \\
\hline & M & 12 & 12 & 100 \\
\hline Cornélio Procópio & $\mathrm{N}$ & 8 & 7 & 87.5 \\
\hline Total & & 262 & 200 & 76.3 \\
\hline
\end{tabular}

Table 2. The frequency of gastrointestinal helminths in free-rage chickens from southern Brazil.

\begin{tabular}{llcc}
\hline \multicolumn{1}{c}{ Helminths } & \multicolumn{1}{c}{ Anatomical location } & \multicolumn{2}{c}{ Chickens infected } \\
\cline { 3 - 4 } Cestodes & & & Number \\
Choanotaenia infundibulum & Small Intestine & 2 & 0.8 \\
Hymenolepis carioca & Small Intestine & 10 & 3.8 \\
Raillietina cesticillus & Small Intestine & 61 & 23.3 \\
Raillietina echinobothrida & Small Intestine & 20 & 7.6 \\
Raillietina tetragona & Small Intestine & 14 & 5.3 \\
Raillietina sp. & Small Intestine & 16 & 6.1 \\
Nematodes & & & \\
Ascaridia galli & Small Intestine & 118 & 45 \\
Capillaria annatis & Cecum; Small Intestine & 16 & 6.1 \\
Capillaria annulata & Crop & 2 & 0.8 \\
Capillaria collaris & Cecum; Small intestine & 2 & 0.8 \\
Capillaria contorta & Crop & 3 & 1.2 \\
Capillaria obsignata & Small Intestine & 5 & 1.9 \\
Capillaria sp. & Cecum; Small Intestine & 6 & 2.3 \\
Dispharynx spiralis & Proventriculus & 6 & 2.3 \\
Heterakis gallinarum & Cecum & 187 & 71.4 \\
Oxyspirura mansoni & Small Intestine & 1 & 0.4 \\
Physaloptera truncata & Crop & 1 & 0.4 \\
Strongyloides oswaldoi & Small Intestine & 6 & 2.3 \\
Subulura brumpti & Cecum & 3 & 1.2 \\
Syngamus trachea & Trachea & 1 & 0.4 \\
Tetrameres americanus & Proventriculus & 3 & 1.2 \\
Tetrameres fissispina & Proventriculus & 1 & 0.4 \\
Trematodes & & & 2.7 \\
Postharmostomum commutatum & Cecum & 7 & \\
\hline
\end{tabular}




\section{Epidemiological findings}

Significant ( $p \leq 0.05$ ) associations were observed when the effects of the types of bedding, soil type, and fence restriction of FRCs were considered relative to the occurrence of helminthic infection in FRCs (Tables 3). The type of bedding, the length of the sanitary break (time without birds in production area), and the presence of shading significantly ( $p$ $\leq 0.05$ ) influenced the occurrence of $H$. gallinarum infections (Table 4). Most parameters evaluated were significantly associated with infection of FRCs by A. galli (Table 5); these included the type of bedding, age when released from cages, age at slaughter, length of the sanitary break, the rearing of other birds, type of soil, and the presence of shading. The relationship between management variables and the occurrence of $H$. gallinarum and A. galli infection were evaluated because these were the most prevalent helminthes in this survey.

Table 3. The relationship between the management systems of free-range chickens from southern Brazil and the susceptibility to infection by helminths.

\begin{tabular}{|c|c|c|c|c|}
\hline Variables evaluated & Possible responses & $\begin{array}{c}\text { Helminths present/ } \\
\text { total }(\%)\end{array}$ & $\mathbf{P}$ & OR $(95 \%$ CI $)$ \\
\hline \multirow[t]{2}{*}{ Type of bedding } & Straw & $127 / 160(79)$ & 0.0003 & $0.16(0.05-0.49)$ \\
\hline & Without bedding & $98 / 102(96)$ & & \\
\hline \multirow[t]{2}{*}{ Age released from cages } & Less than 30 days & 166/193 (86) & 0.9216 & $1.04(0.44-2.44)$ \\
\hline & More than 30 days & $59 / 69(85)$ & & \\
\hline \multirow[t]{2}{*}{ Slaughter age } & Less than 100 days & $180 / 205(87)$ & 0.1379 & $1.92(0.83-4.40)$ \\
\hline & More than 100 days & $45 / 57(78)$ & & \\
\hline \multirow[t]{2}{*}{ Water source } & Water basin & 129/149 (86) & 0.8560 & $1.14(0.53-2.44)$ \\
\hline & Artesian well & $96 / 113(84)$ & & \\
\hline \multirow[t]{2}{*}{ Sanitary break } & Less than 60 days & 173/193 (89) & 0.0876 & $2.03(0.91-2.45)$ \\
\hline & More than 60 days & $52 / 66(79)$ & & \\
\hline \multirow[t]{2}{*}{ Rearing of other birds } & Yes & $48 / 52(79)$ & 0.2059 & $2.24(0.70-7.93)$ \\
\hline & No & $177 / 210(84)$ & & \\
\hline \multirow[t]{2}{*}{ Fence restriction } & Yes & $162 / 195(83)$ & 0.0436 & $0.31(0.09-0.98)$ \\
\hline & No & 63/67 (94) & & \\
\hline \multirow[t]{2}{*}{ Soil type } & Clay & $153 / 186(82)$ & 0.0148 & $0.26(0.07-0.80)$ \\
\hline & Sandy/Mixed & $72 / 76(94)$ & & \\
\hline \multirow[t]{2}{*}{ Stocking capacity } & Below $3 \mathrm{~m}^{2} /$ bird & 9/9 (100) & 0.3674 & $1.17(1.11-1.23)$ \\
\hline & Above $3 \mathrm{~m}^{2} /$ bird & $216 / 253(85)$ & & \\
\hline \multirow[t]{2}{*}{ Presence of shading } & Yes & $177 / 210(84)$ & 0.2059 & $0.45(0.13-1.42)$ \\
\hline & No & $48 / 52(92)$ & & \\
\hline
\end{tabular}


Table 4. The relationship between the management systems of free-range chickens from southern Brazil and the susceptibility to infection by Heterakis gallinarum.

\begin{tabular}{|c|c|c|c|c|}
\hline Variables evaluated & Possible responses & Helminths present/total (\%) & $\mathbf{P}$ & OR (95\% CI) \\
\hline \multirow[t]{2}{*}{ Type of bedding } & Straw & $105 / 160(65)$ & 0.014 & $0.47(0.25-0.87)$ \\
\hline & Without bedding & $82 / 102(80)$ & & \\
\hline \multirow[t]{2}{*}{ Age released from cages } & Less than 30 days & 136/193 (70) & 0.6976 & $0.84(0.43-1.64)$ \\
\hline & More than 30 days & $51 / 69(73)$ & & \\
\hline \multirow[t]{2}{*}{ Slaughter age } & Less than 100 days & $142 / 205(70)$ & 0.7867 & $0.86(0.42-1.76)$ \\
\hline & More than 100 days & $42 / 57(73)$ & & \\
\hline \multirow[t]{2}{*}{ Water source } & Water basin & 109/149 (73) & 0.5524 & $1.22(0.68-2.18)$ \\
\hline & Artesian well & $78 / 113(69)$ & & \\
\hline \multirow[t]{2}{*}{ Sanitary break } & Less than 60 days & 149/193 (76) & 0.0067 & $2.34(1.24-4.41)$ \\
\hline & More than 60 days & $38 / 66(57)$ & & \\
\hline \multirow[t]{2}{*}{ Rearing of other birds } & Yes & $45 / 52(86)$ & 0.0133 & $3.08(1.24-7.98)$ \\
\hline & No & $142 / 210(71)$ & & \\
\hline \multirow[t]{2}{*}{ Fence restriction } & Yes & 139/195 (71) & 0.9199 & $0.98(0.50-1.91)$ \\
\hline & No & $48 / 67(71)$ & & \\
\hline \multirow[t]{2}{*}{ Soil type } & Clay & 130/186 (69) & 0.049 & $0.77(0.40-1.48)$ \\
\hline & Sandy/Mixed & $57 / 76(75)$ & & \\
\hline \multirow[t]{2}{*}{ Stocking capacity } & Below $3 \mathrm{~m}^{2} /$ bird & 9/9 (100) & 0.0636 & $1.42(1.31-1.54)$ \\
\hline & Above $3 \mathrm{~m}^{2} /$ bird & $178 / 253(70)$ & & \\
\hline \multirow[t]{2}{*}{ Presence of shading } & Yes & $141 / 210(67)$ & 0.0040 & $0.27(0.10-0.70)$ \\
\hline & No & $46 / 52(88)$ & & \\
\hline
\end{tabular}

Table 5. The relationship between the management systems of free-range chickens from southern Brazil and the susceptibility to infection by Ascaridia galli.

\begin{tabular}{|c|c|c|c|c|}
\hline Variables evaluated & Possible responses & Helminths present/total (\%) & $\mathbf{P}$ & OR (95\% CI) \\
\hline \multirow[t]{2}{*}{ Type of bedding } & Straw & $55 / 160(34)$ & 0.000024 & $0.32(0.19-0.56)$ \\
\hline & Without bedding & 63/102 (62)) & & \\
\hline \multirow[t]{2}{*}{ Age released from cages } & Less than 30 days & $95 / 193(49)$ & 0.0326 & $1.94(1.05-3.61)$ \\
\hline & More than 30 days & $23 / 69(33)$ & & \\
\hline \multirow[t]{2}{*}{ Slaughter age } & Less than 100 days & $104 / 205(50)$ & 0.0007 & $3.16(1.55-6.53)$ \\
\hline & More than 100 days & $14 / 57(24)$ & & \\
\hline \multirow[t]{2}{*}{ Water source } & Water basin & $70 / 149(46)$ & 0.5484 & $1.20(0.71-2.03)$ \\
\hline & Artesian well & $48 / 113(42)$ & & \\
\hline \multirow[t]{2}{*}{ Sanitary break } & Less than 60 days & 104/193 (53) & 0.0001 & $4.20(2.08-8.58)$ \\
\hline & More than 60 days & $14 / 66(21)$ & & \\
\hline \multirow[t]{2}{*}{ Rearing of other birds } & Yes & $12 / 52(23)$ & 0.0004 & $0.35(0.19-0.65)$ \\
\hline & No & $106 / 210(50)$ & & \\
\hline \multirow[t]{2}{*}{ Fence restriction } & Yes & 139/195 (71) & 0.9199 & $0.98(0.50-1.91)$ \\
\hline & No & $48 / 67(71)$ & & \\
\hline \multirow[t]{2}{*}{ Soil type } & Clay & $68 / 186(36)$ & 0.000029 & $0.30(0.16-0.54)$ \\
\hline & Sandy/Mixed & $50 / 76(65)$ & & \\
\hline \multirow[t]{2}{*}{ Stocking capacity } & Below $3 \mathrm{~m}^{2} /$ bird & $7 / 9(77)$ & 0.0953 & $4.48(0.82-32.29)$ \\
\hline & Above $3 \mathrm{~m}^{2} /$ bird & $111 / 253(43)$ & & \\
\hline \multirow[t]{2}{*}{ Presence of shading } & Yes & $105 / 210(50)$ & 0.0020 & $3.0(1.44-6.35)$ \\
\hline & No & $13 / 52(25)$ & & \\
\hline
\end{tabular}




\section{Discussion}

This study represents a novelty in the understanding of helminths in FRCs from Brazil since it allowed for the detection of management variables associated with the risk of helminthic infection within a subtropical region. Alternatively, questionnaires were used to evaluate the association between variables and helminthic infection in free-land laying hens from England and Wales (SHERWIN et al., 2013); and blackhead disease in turkeys from France (CALLAIT-CARDINAL et al., 2010). Factors such as hygiene and density were associated with parasite infection.

The results from this study suggest that the type of floor bedding, the soil type, and the usage of fences in the management of FRCs were directly related to gastrointestinal helminthiasis in FRCs, while the stocking density and the source of water had no significant effect on the development of gastrointestinal parasitism in FRCs.

It has been suggested that the depth of straw is associated with a reduced infection by $A$. galli (SHERWIN et al., 2013). In addition, protection of up to eight weeks due to the introduction of new straw in layer houses has been described (MAURER et al., 2009). Similar results were observed during this study where the usage of straw as floor bedding compared without any floor bedding reduced the possibility of FRCs being infected by $H$. gallinarum and $A$. galli probably due to restricted contact with the infectious stages of these parasites. Furthermore, in the current study the stocking density $\left(3 \mathrm{~m}^{2}\right.$ per bird) was not associated with parasitism, while the stocking density of the hens $\left(5-10 \mathrm{~m}^{2}\right.$ per bird) reared outdoors seemed not to influence the transmission patterns of $A$. galli and $H$. gallinarum (HECKENDORN et al., 2009). Moreover, the providing of sand within the litter area was associated with an increase in fecal egg counts for Ascaridia, Heterakis and Trichostrongylus (SHERWIN et al., 2013); these findings are in agreement with the association between sandy soil, helminth infection $(\mathrm{P}=0.0148)$ and $A$. galli infection $(\mathrm{P}=0.000029)$ seen in this research.

An important finding was that FRCs reared in management systems that used sanitary breaks for less than 60 days have a more elevated risk of being infected by $H$. gallinarum ( $\mathrm{p}=0.0067$; OR, 2.34; CI 1.24-4.41) and A. galli ( $\mathrm{p}=0.0001 ; \mathrm{OR}, 4.20 ; \mathrm{CI}$, $2.08-8.58$ ). This can be associated with the fact that the infective capacity of the ovum of $H$. gallinarum and $A$. galli is progressively reduced when exposed to the adverse effects of environmental conditions (SMITH, 1998; MERCADO et al., 2004). Moreover, elevated soil temperatures have been associated with reduced infectivity of the eggs of H. gallinarum and A. galli (CHRISTENSON et al., 1942; TARBIAT, 2012), while desiccation was considered as detrimental to the viability of the eggs of A. galli (CARDOZO; YAMAMURA, 2004; TARBIAT, 2012).

This study has demonstrated that the average frequency of parasitism in FRCs from all rural regions evaluated was $76.3 \%$. Prevalence levels in FRCs has been described as $62 \%$ in Zaria, Nigeria (LUKA; NDAMS, 2007), 89.9\% in Morocco (HASSOUNI; BELGHYTI, 2006), 89.5\% in the Shewa Zone (HUSSEN et al., 2012) and 91\% in the Amhara region (ESHETU et al., 2001) of Ethiopia, 92.7\% in Lages, Santa Catarina, southern Brazil (VIERO, 1984), 97\% in Kampala, Uganda (SSENYONGA, 1982), and $100 \%$ in Tanzania (MAGWISHA et al., 2002). These results suggest that gastrointestinal parasitism is a major problem for FRCs worldwide, and reinforces the theory that all FRCs are probably subclinically infected by intestinal helminths (MAGWISHA et al., 2002).

Although cestodes, nematodes and trematodes were identified in the present study from all regions evaluated, parasitism was predominantly due to cestodes and nematodes, with most infections being associated primarily with $H$. gallinarum and $A$. galli. Additionally, a comparative analysis of published data from Brazil suggests that H. gallinarum, A. galli, 
Raillietina spp. are probably the most frequently occurring helminths in FRCs (Table 6). Similar results have been described in FRCs from other regions of Brazil (VIERO, 1984; GOMES et al., 2009), as well as from other countries such as Iran (ESLAMI et al., 2009), Bangladesh (RABBI et al., 2006), Zimbabwe (DUBE et al., 2010), and Ethiopia (ESHETU et al., 2001). These findings suggest that $H$. gallinarum and
A. galli are probably the principal intestinal helminths of FRCs worldwide, represent an ongoing problem, and contribute to the elevated rates of mortality in FRCs (GOMES et al., 2009). This is probably due to the scavenging habits of FRCs which favor the ingestion of earthworms (RABBI et al., 2006), the paratenic hosts of $H$. gallinarum and $A$. galli, as well as the infectious stages of these parasites.

Table 6. Distribution of gastrointestinal helminths in free-range chickens from different geographical regions of Brazil.

\begin{tabular}{|c|c|c|c|c|c|c|c|c|}
\hline \multirow[b]{2}{*}{ Helminths } & \multicolumn{8}{|c|}{ References consulted } \\
\hline & $\begin{array}{l}\text { This } \\
\text { study }\end{array}$ & $\begin{array}{c}\text { Costa } \\
\text { et al., } \\
1975\end{array}$ & $\begin{array}{c}\text { Albuquerque, } \\
1977\end{array}$ & $\begin{array}{l}\text { Carneiro } \\
\text { et al., } 1979\end{array}$ & $\begin{array}{l}\text { Machado } \\
\text { et al., } 1980\end{array}$ & $\begin{array}{l}\text { Reis } \\
\text { et al., } \\
1980\end{array}$ & $\begin{array}{l}\text { Pavanelli } \\
\text { et al., } 1981\end{array}$ & $\begin{array}{l}\text { Viero, } \\
1984\end{array}$ \\
\hline \multirow[t]{2}{*}{$\mathrm{n} /$ Region } & $262 / \mathrm{S}$ & $30 / \mathrm{SE}$ & $203 / \mathrm{S}$ & 33/MW & $31 / \mathrm{SE}$ & $36 / \mathrm{NE}$ & $121 / \mathrm{S}$ & $205 / \mathrm{S}$ \\
\hline & $\%$ & $\%$ & $\%$ & $\%$ & $\%$ & $\%$ & $\%$ & $\%$ \\
\hline \multicolumn{9}{|l|}{ Cestodes } \\
\hline $\begin{array}{l}\text { Choanotaenia } \\
\text { infundibulum }\end{array}$ & 0.8 & & & 3 & & & 19 & \\
\hline Hymenolepis carioca & 3.8 & & & & & & 2.5 & 5.36 \\
\hline Raillietina cesticillus & 23.3 & 26.6 & & 30 & 6.5 & 5.6 & 32.2 & 11.7 \\
\hline $\begin{array}{l}\text { Raillietina } \\
\text { echinobothrida }\end{array}$ & 7.6 & 23.3 & & 33 & 45.2 & 2.8 & 2.5 & \\
\hline Raillietina tetragona & 5.3 & 70 & & 36 & 41.9 & 2.8 & 62 & 13.7 \\
\hline Raillietina sp. & 6.1 & & 59 & & & & & \\
\hline \multicolumn{9}{|l|}{ Nematodes } \\
\hline Ascaridia galli & 45 & 60 & 58 & 27 & 41.9 & 44.5 & 43.8 & 32.7 \\
\hline Capillaria annatis & 6.1 & & & & 3.2 & & & \\
\hline Capillaria annulata & 0.8 & 36.6 & & & 3.2 & & 4.9 & 0.9 \\
\hline Capillaria collaris & 0.8 & & & & & & 12.4 & 52.2 \\
\hline Capillaria contorta & 1.2 & & & & 9.7 & 5.6 & & \\
\hline Capillaria obsignata & 1.9 & 56.6 & & & 12.9 & 2.8 & 0.8 & 27.3 \\
\hline Capillaria sp. & 2.3 & & 86 & 12 & & & & \\
\hline Dispharynx spiralis & 2.3 & & 1 & & 12.9 & & 24.8 & \\
\hline Heterakis gallinarum & 71.4 & 63.3 & 81 & 75 & 87.1 & 22.5 & 85.9 & 75.6 \\
\hline Oxyspirura mansoni & 0.4 & 60 & & & 59.1 & & & \\
\hline Physaloptera truncata & 0.4 & & & & & & & \\
\hline $\begin{array}{l}\text { Strongyloides } \\
\text { oswaldoi }\end{array}$ & 2.3 & & & 6 & & & & \\
\hline Subulura brumpti & 1.2 & & & & & & & \\
\hline Syngamus trachea & 0.4 & & & & 6.5 & 5.6 & & \\
\hline $\begin{array}{l}\text { Tetrameres } \\
\text { americanus }\end{array}$ & 1.2 & & 40 & & & & & \\
\hline $\begin{array}{l}\text { Tetrameres fissispina } \\
\text { Trematodes }\end{array}$ & 0.4 & & & & & & 9.9 & \\
\hline $\begin{array}{l}\text { Postharmostomum } \\
\text { commutatum }\end{array}$ & 2.7 & 3,3 & & & 9.7 & & & 0.5 \\
\hline
\end{tabular}

Legend: S, southern; SE, southeastern; MW, Midwest; NE, northeastern. 
An adult Oxyspirura mansoni was found in the small intestine, probably due to contamination in the slaughterhouse or during transport to the laboratory. Its natural habitat is the eye and lachrymal duct of their hosts (VICENTE et al., 1995; PERMIN; HANSEN, 1998).

In conclusion, the high prevalence and worm burden found indicate favorable environmental conditions for helminth infection in free-range system on the Brazilian subtropical region. Thus, preventive techniques are necessary and should be implemented during the rearing of FRCs. These include decreased shading, use of adequate floor beddings, and greater sanitary breaks, which might avoid contamination and reduce the viability of the parasitic infectious forms within the soil thereby resulting in increased efficiency and productivity. However, we believe that additional epidemiological studies should be done to investigate the associations between the variables evaluated and to better identify the factors that may affect the occurrence of helminths, thereby contributing to the establishment of new husbandry techniques.

\section{References}

ALBUQUERQUE, B. D. L. Fauna helmíntica de Gallus gallus domesticus (Lin.) de criação em fundo de quintal em Porto Alegre - RS. 1977. Dissertação (Mestrado em Medicina Veterinária) - Universidade Federal do Rio Grande do Sul, Porto Alegre.

BERG, C. Health and welfare in organic poultry production. Acta Veterinaria Scandinavica, London, v. 43, p. S37-S45, 2002. Supplement 1.

BHERING, S. B.; SANTOS, H. G. Mapas de solos do Estado do Paraná: legenda atualizada. Rio de Janeiro: EMBRAPA Solos, 2008.

CALLAIT-CARDINAL, M. P.; GILOT-FROMONT, E.; CHOSSAT, L.; GONTHIER, A.; CHAUVE, C.; ZENNER, L. Flock management and histomoniasis in free-range turkeys in France: description and search for potential risk factors. Epidemiology and infection, Cambridge, v. 138, n. 3, p. 353-363, 2010.

CARDOZO, S. P.; YAMAMURA, M. H. Parasitas em produção de frangos no sistema de criação tipo colonial/ caipira no Brasil. Semina: Ciências Agrárias, Londrina, v. 25 , n. 1, p. 63-74, 2004.

CARNEIRO, J. R.; CAMPOS, D. M. B.; LUSTOSA, E. S.; PEREIRA, E. Ocorrência de helmintos gastrintestinais em Gallus gallus domesticus no município de Goiânia. Arquivos da Escola de Veterinária da UFMG, Belo Horizonte, v. 31, n. 1, p. 37-38, abr. 1979.

CHRISTENSON, R. O.; EARLE, J. H. H.; BUTLER JÚNIOR, R. L.; CREEL, H. H. Studies on the eggs of Ascaridia galli and Heterakis gallinae. Transactions of the American Microscopical Society, Lawrence, v. 61, n. 2, p. 191-205, 1942.

COSTA, H. M.; LEITE, A. C. R.; GUIMARÃES, M. P.; LIMA, A. S. Distribuição de helmintos parasitos de animais domésticos no Brasil. Arquivo Brasileiro de Medicina Veterinária e Zootecnia, Belo Horizonte, v. 31, n. 4, p. 465-579, 1986.

DEAN, A. G.; DEAN, J. A.; COULOMBIER, D.; BURTON, A. H.; BRENDEL, K. A.; SMITH, D. C.; DICKER, R. C.; SULLIVAN, K. M.; FAGAN, R. F. Epi Info, version 6: a word processing, database, and statistics program for public health on IBM-compatible microcomputers. Atlanta, Georgia: Centers for Disease Control and Prevention, 1996.

DUBE, S.; ZINDI, P.; MBANGA, J.; DUBE, C. A study of scavenging poultry gastrointestinal and ecto-parasites in rural areas of Matebeleland Province, Zimbabwe. International Journal of Poultry Science, Faisalabad, v. 9, n. 9, p. 911-915, 2010.

ESHETU, Y.; MULUALEM, E.; IBRAHIM, H.; BERHANU, A.; ABERRA, K. Study of gastro-intestinal helminths of scavenging chickens in four rural districts of Amhara region, Ethiopia. Revue Scientifique et Technique (Office International des Epizooties), Paris, v. 20, n. 3, p. 791-796, 2001.

ESLAMI, A.; GHAEMI, P.; RAHBARI, S. Parasitic infections of free - range chickens from Golestan Province, Iran. Iranian Journal of Parasitology, Tehran, v. 4, n. 3, p. 101-114, 2009.

FOSSUM, O.; JANSSON, D.; ETTERLIN, P.; VAGSHOLM, I. Causes of mortality in laying hens in different housing systems in 2001 to 2004. Acta Veterinaria Scandinavica, London, v. 51, n. 3, p. 1-9, 2009.

GOMES, F. F.; MACHADO, H. H. S.; LEMOS, L. D. S.; ALMEIDA, L. G. D.; DAHER, R. F. Main intestinal parasites diagnosed in domestic chickens raised in extensive regimen in the municipality of Campos dos Goytacazes, RJ. Ciência Animal Brasileira, Goiânia, v. 10, n. 3, p. 818-822, 2009. 
HASSOUNI, T.; BELGHYTI, D. Distribution of gastrointestinal helminths in chicken farms in the Gharb region-Morocco. Parasitology Research, Berlin, v. 99, n. 2, p. 181-183, 2006.

HECKENDORN, F.; HARING, D. A.; AMSLER, Z.; MAURER, V. Do stocking rate and a simple run management practice influence the infection of laying hens with gastrointestinal helminths? Veterinary Parasitology, Amsterdam, v. 159, n. 1, p. 60-68, 2009.

HUSSEN, H.; CHAKA, H.; DENEKE, Y.; BITEW, M. Gastrointestinal helminths are highly prevalent in scavenging chickens of selected districts of Eastern Shewa Zone, Ethiopia. Pakistan Journal of Biological Sciences, Faisalabad, v. 15, n. 6, p. 284-289, 2012.

LUKA, S. A.; NDAMS, I. S. Gastrointestinal parasites of domestic chicken Gallus-gallus domesticus Linnaeus 1758 in Samaru, Zaria Nigeria. Science World Journal, Kaduna, v. 2, n. 1, p. 27-29, 2007.

MACHADO, R. Z.; COSTA, J. O.; KASAI, N.; COSTA, A. J. Helmintos parasitos de Gallus gallus domesticus (L) do munícipio de Jaboticabal, Sao Paulo. Arquivos da Escola de Veterinaria da Universidade Federal de Minas Gerais, Belo Horizonte, v. 32, n. 2, p. 241-243, 1980.

MAGWISHA, H. B.; KASSUKU, A. A.; KYVSGAARD, N. C.; PERMIN, A. A comparison of the prevalence and burdens of helminth infections in growers and adult freerange chickens. Tropical Animal Health and Production, Edinburgh, v. 34, n. 3, p. 205-214, 2002.

MAURER, V.; AMSLER, Z.; PERLER, E.; HECKENDORN, F. Poultry litter as a source of gastrointestinal helminth infections. Veterinary Parasitology, Amsterdam, v. 161, n. 3-4, p. 255-260, 2009.

MERCADO, R.; UETA, M. T.; CASTILLO, D.; MUÑOZ, V.; SCHENONE, H. Exposure to larva migrans syndromes in squares and public parks of cities in Chile. Revista de Saúde Pública, São Paulo, v. 38, n. 5, p. 729731, 2004.

MINISTÉRIO DA AGRICULTURA, PECUÁRIA E ABASTECIMENTO - MAPA. Dispõe sobre registro do produto frango caipira ou frango colonial ou frango tipo ou estilo caipira ou tipo ou estilo colonial. Brasília : Ministério da Agricultura e do Abastecimento, 1999.

OLIVARES, L. L.; KYVSGAARD, N.; RIMBAUD, E.; PINEDA, N. Prevalencia y carga parasitaria de helmintos gastrointestinales en gallinas de traspatio (Gallus Gallus Domesticus), en el municipio de El Sauce, departamento de León, Nicaragua. Revista Electrónica de Veterinaria, Málaga,v; 7, n. 11, p. 1-4, 2006.
PAVANELLI, G. C. Helmintofauna de Gallus gallus domesticus (LIN.,1758) (Galliformes, Phasianidae) criados em fundo de quintal no município de Maringá - Paraná. 1981. Dissertação (Mestrado em Zoologia) Universidade Federal de Paraná, Curitiba.

PERMIN, A.; HANSEN, J. W. The epidemiology, diagnosis and control of poultry parasites. Rome: FAO Animal Health Manual, 1998. 167 p.

RABBI, A. K. M. A.; ISLAM, A.; MAJUMDER, S.; ANISUZZAMAN, A.; RAHMAN, M. H. Gastrointestinal helminths infection in different types of poultry. Bangladesh Journal of Veterinary Medicine, Mymensingh, v. 4, n. 1, p. 13-18, 2006.

RAHMAN, A. W.; SALIM, H.; GHAUSE, M. S. Helminthic parasites of scavenging chickens (Gallus domesticus ) from Villages in Penang Island, Malaysia. Tropical Life Sciences Research, Pulau Pinang, v. 20, n. 1, p. 1-6, 2009.

REIS, C. H. L.; OLIVEIRA, P. E.; BAVIA, E. M. Investigação parasitológica em Gallus gallus domesticus (L., 1758) naturalmente infectados na região de Salvador - Bahia. Arquivos da Escola de Medicina Veterinária da Universidade Federal da Bahia, Salvador, v. 5, n. 1, p. 75-83, 1980.

RUFF, M. D. Important parasites in poultry production systems. Veterinary Parasitology, Amsterdam, v. 84, n. 3-4, p. 337-347, 1999.

RUMEL, D. Odds ratio: algumas considerações. Revista de Saúde Pública, São Paulo, v. 20, n. 3, p. 253-258, 1986.

SCHMIDT, G. D. CRC handhook of tapeworm identification. Boca Raton, Florida: CRC Press Inc, 1986. $688 \mathrm{p}$.

SHERWIN, C. M.; NASR, M. A.; GALE, E.; PETEK, M.; STAFFORD, K.; TURP, M.; COLES, G. C. Prevalence of nematode infection and faecal egg counts in free-range laying hens: relations to housing and husbandry. British Poultry Science, London, v. 54, n. 1, p. 12-23, 2013.

SMITH, H. V. Detection of parasites in the environment. Parasitology, Cambridge, v. 117, p. S113-141, 1998. Spplement.

SOULSBY, E. J. L. Helminths, arthropods and protozoa of domesticated animals. $7^{\text {th }}$ ed. London: Bailliere Tindall, $1982.809 \mathrm{p}$.

SSENYONGA, G. S. Prevalence of helminth parasites of domestic fowl (Gallus domesticus) in Uganda. Tropical Animal Health and Production, Edinburgh, v. 14, n. 4, p. 201-204, 1982. 
TARBIAT, B. Environmental tolerance of the free-living stages of the poultry roundworm (Ascaridia galli). 2012. Dissertation (Master in Veterinary Medicine and Animal Science) - Department of Biomedical Sciences and Veterinary Public Health Parasitology. Swedish University of Agricultural Sciences. Uppsala, Sweeden.

THRUSFIELD, M. Veterinary epidemiology. $3^{\text {th }}$ ed. Oxford, UK: Blackwell Science, 2005. 610 p.

TRAVASSOS, L.; TEIXEIRA DE FREITAS, J. F.; KOHN, A. Trematódeos do Brasil. Memórias do Instituto Oswaldo Cruz, Rio de Janeiro, v. 67, n. 1, p. 1-886, 1969.

VICENTE, J. J.; RODRIGUES, H. D. O.; GOMES, D. C.; PINTO, R. M. Nematóides do Brasil. Parte IV: nematóides de aves. Revista Brasileira de Zoologia, Curitiba, v. 12, p. 1-273, 1995. Suplemento 1.
VIERO, M. H. Incidência helmíntica em Gallus gallus domesticus (L.) criados em fundo de quintal na microrregião dos Campos de Lages, Santa Catarina. Acta Biológica Paranaense, Curitiba, v. 13, n. 1, 2, 3, 4, p. 123-135, 1984.

YAMAGUTI, S. Sistema helminthum: the cestodes of vertebrates. New York: Interscience, 1959. 860 p.

Sistema helminthum: the nematodes of vertebrates. New York: Interscience, 1961. 1274 p.

YORIYO, K. P.; ADANG, K. L.; FABIYI, J. P.; ADAMU, S. U. Helminthes parasites of local chickens in Bauchi State, Nigeria. Science World Journal, Kaduna, v. 3, n. 2, p. 35-37, 2008. 